\title{
Three new species of Pristimantis (Lissamphibia, Anura) from montane forests of the Cordillera Yanachaga in Central Peru
}

\author{
William E. Duellman ${ }^{1}$ and S. Blair Hedges ${ }^{2}$ \\ 1 Natural History Museum and Biodiversity Research Center, University of Kansas, 1345 Jayhawk Blvd., Lawrence, \\ Kansas 66045, USA. E-mail: duellman@ku.edu. \\ 2 Department of Biology, 208 Mueller Laboratory, Pennsylvania State University, University Park, Pennsylvania 16802, \\ USA.
}

\begin{abstract}
Three new species of Pristimantis (Lissamphibia, Anura) from montane forests of the Cordillera Yanachaga in Central Peru. We describe three additional new species of Pristimantis from the Cordillera Yanachaga, a part of the Andes in central Peru. Analyses of DNA sequences of the mitochondrial rRNA genes show that one species is a close relative of $P$. bipunctatus ( $P$. conspicillatus Group), another is a close relative of $P$. stictogaster ( $P$. peruvianus Group), and the third is related to several species in the $P$. unistrigatus Group. The first two species are morphologically similar to their closest relatives but occur at lower elevations. Twenty-nine species of Pristimantis and Phrynopus are known from the vicinity of the Cordillera Yanachaga. The number of species, especially of Pristimantis, is high in the humid montane forest in comparison with other sites in humid montane forests in Peru, but the number is lower than on the western slopes of the Andes in Ecuador.
\end{abstract}

Keywords: Anura, Pristimantis adiastolus sp. nov., Pristimantis albertus sp. nov., Pristimantis minutulus sp. nov., Phrynopus, species diversity, cryptic species, Andes, Yanachaga-Chemillén.

\section{Resumen}

Tres especies nuevas de Pristimantis (Lissamphibia: Anura) en los bosques montanos de la Cordillera Yanachaga en el centro del Perú. Describimos tres especies nuevas de Pristimantis provenientes de la Cordillera Yanachaga, en los Andes del centro del Perú. Los análisis de las secuencias de ADN mitocondrial de genes ribosomales muestran que una de las especies está cercanamente relacionada con $P$. bipunctatus (Grupo P. conspicillatus), la segunda especie con P. stictogaster (Grupo 
P. peruvianus) y la tercera con varias especies del Grupo P. unistrigatus. Las primeras dos especies son morfológicamente similares a sus respectivas especies hermanas, pero sin embargo habitan en elevaciones más bajas. Se conocen 29 especies de ranas del g'nero Phrynopus y Pristimantis en las inmediaciones de la Cordillera Yanachaga. Esta diversidad de especies, particularmente de Pristimantis, es elevada en comparación con otras localidades de características similares en el Perú; sin embargo, es menor a la reportada en la vertiente occidental de los Andes del Ecuador.

Palabras clave: Anura, Pristimantis adiastolus sp. nov., Pristimantis albertus sp. nov., Pristimantis minutulus sp. nov., Phrynopus, diversidad de especies, especies crípticas, Andes, Yanachaga-Chemillén.

\section{Introduction}

It is well known that the Amazonian slopes of the Andes harbor many species of frogs, especially species of "eleutherodactylines". This high level of diversity was noted by Lynch (1979) and Lynch and Duellman (1980) for the Andes in Ecuador and by Duellman and Pramuk (1999) for the Andes in northern Peru. Duellman (1978a, b) described seven species of Eleutherodactylus (= Pristimantis Jiménez de la Espada, 1871 (fide Heinicke et al., 2007) P. cosnipatae, danae, lindae, mendax, pharangobates, salaputium, and toftae) from the Andes in Departamento Cusco in southern Peru; Lehr (2007) named three more species ( $P$. seorsus, tanyrhynchus, and vilcabambae) from there. Padial et al. (2006) reported $P$. mercedesae Lynch and McDiarmid, 1987, from there, and one of us (WED) has examined specimens of $P$. olivaceus Köhler, Morales, Lötters, Reichle, and Aparicio, 1998, and P. platydactylus Boulenger, 1903, from Departamento de Cusco, where in the Andes additional species are placed in other generaPhrynopus Peters, 1874 (5 species), and Oreobates Jiménez de la Espada, 1872 (1 species), but these generic assignments are being changed by Hedges et al. (2008).

It is now becoming obvious that there is a high level of diversity of Pristimantis in the Andes of central Peru in the Departamentos Ayacucho, Huánuco, Junín, and Pasco. Duellman (1978c) named P. rhabdolaemus and
P. scitulus. Lehr et al. (2004) described P. sagittulus, and Duellman and Hedges (2005) named $P$. aniptopalmatus, bipunctatus, rhabdocnemus, and stictogaster and reported $P$. bromeliaceus Lynch, 1979, and P. mendax. Lehr et al. (2006) described P. cruciocularis, flavobracatus, ornatus, and pardalinus and reported the northernmost records of $P$. platydactylus. Boano et al. (in press) are naming another Pristimantis. In addition to these 15 species of Pristimantis, Duellman and Hedges (in press) and Chaparro et al. (in press) reported 21 species of Phrynopus Peters, 1874, mostly from elevations higher than those inhabited by Pristimantis. Other "eleutherodactylines" in the region are "Eleutherodactylus" lucida (Cannatella, 1984), “E.” lundbergi (Lehr, 2005), “E.” pereger (Lynch, 1975), and Phyllonastes duellmani (Lehr, Aguilar, and Lundberg, 2004). With the addition of three new species of Pristimantis described herein, the total number of "eleutherodactylines" in the central Peruvian Andes is now 40 species; of these, 15 are known from a relatively small area, the Cordillera de Yanachaga, a range lying to the east of the main part of the Cordillera Oriental.

\section{Material and Methods}

Treatment of the animals in the field followed standardized guidelines (Anonymous 1987). Color photographs were taken of living frogs. Subsequently, frogs were euthanized in ice water, tissues were removed and stored in 
liquid nitrogen, and specimens were fixed in $10 \%$ formalin and later transferred to $70 \%$ ethanol. The format for the diagnoses and descriptions of the new species follow those of Lynch and Duellman (1997) with the exception that dentigerous processes of vomers is used in place of vomerine odontophores. Generic and species group allocations correspond to the classification proposed by Hedges et al. (2008). Comparisons are made with other species in the Andes in central Peru. Measurements were taken with dial calipers and rounded to the nearest 0.1 $\mathrm{mm}$. Snout-vent length is abbreviated SVL throughout. Specimens examined are listed in the appendix; codes of collections are those of Leviton et al. (1985) with the addition of MHNC $=$ Museo de Historia Natural Universidad Nacional de San Antonio Abad, Cusco, Peru; MUSM = Museo de Historia Natural Universidad Nacional Mayor San Marcos, Lima, Peru; and MTD = Staatliche Naturhistorische Sammlungen Dresden, Museum für Tierkunde, Germany.

\section{Species Descriptions}

\section{Pristimantis adiastolus sp. nov.}

(Figure 1A)

Holotype - KU 291681, an adult male, from 1.5 km NW Cacazú, 1200 m, 10³8’S, $75^{\circ} 07^{\prime} \mathrm{W}$, Departamento Pasco, Peru, obtained on 9 July 1987 by S. Blair Hedges.

Etymology - The specific name is derived from the Greek adiastolos, meaning not separated or confused. The name is used in reference to the similarity of this species with Pristimantis bipunctatus.

Diagnosis - This member of the Pristimantis (Pristimantis) peruvianus Group is characterized by (1) skin on dorsum shagreen; that on venter weakly areolate; discoidal fold present; dorsolateral folds present; (2) tympanic membrane differentiated; tympanic annulus prominent; (3) snout long, narrow, bluntly rounded in dorsal view, nearly truncate in profile; (4) upper eyelid lacking tubercles, narrower than interorbital distance; cranial crests absent; (5) dentigerous processes of vomers prominent, oblique; (6) vocal slits present; nuptial pads absent; (7) Finger I slightly shorter than Finger II; discs on fingers elliptical, about twice width of digit proximal to pad; (8) fingers lacking lateral fringes; (9) ulnar tubercles low, diffuse; (10) heel and outer edge of tarsus lacking tubercles; inner edge of tarsus bearing weak fold distally; (11) inner metatarsal tubercle elongately elliptical, about $4 \times$ subconical outer metatarsal tubercle; supernumerary plantar tubercles minute; (12) toes lacking lateral fringes; webbing basal; Toe V slightly longer than Toe III; discs smaller than those on outer fingers; (13) dorsum tan with brown chevrons; venter cream with brown mottling on throat; posterior surfaces of thighs brown; (14) SVL $28.0 \mathrm{~mm}$ in one male, unknown in females.

Pristimatis adiastolus and P. bipunctatus are cryptic species that have similarities in structure (weakly areolate belly, long snout, and long legs) and coloration (pattern of dorsal chevrons, black scapular spots, and brown mottling on the throat). However, $P$. adiastolus has prominent dorsolateral folds (low and barely discernable in $P$. bipunctatus; Figure 1A, B), Finger I slightly shorter than Finger II (Fingers I and II equal in length in $P$. bipunctatus), and distinctly shorter digits (Figure 1A, B). In coloration, the posterior surfaces of the thighs are uniform brown in $P$. adiastolus, whereas those of $P$. bipunctatus are brown with cream flecks. Eight other Peruvian members of the Pristimantis conspicillatus and peruvianus groups, both characterized by Toe V being only slightly longer than Toe III, are like $P$. adiastolus in having dorsolateral folds and areolate skin on the belly. Of these, $P$. avicuporum Duellman and Pramuk, 1999, and P. skydmainos Flores and Rodríguez, 1997, have Finger I longer than Finger II; also, the latter differs from $P$. adiastolus by having an interocular fold and a 

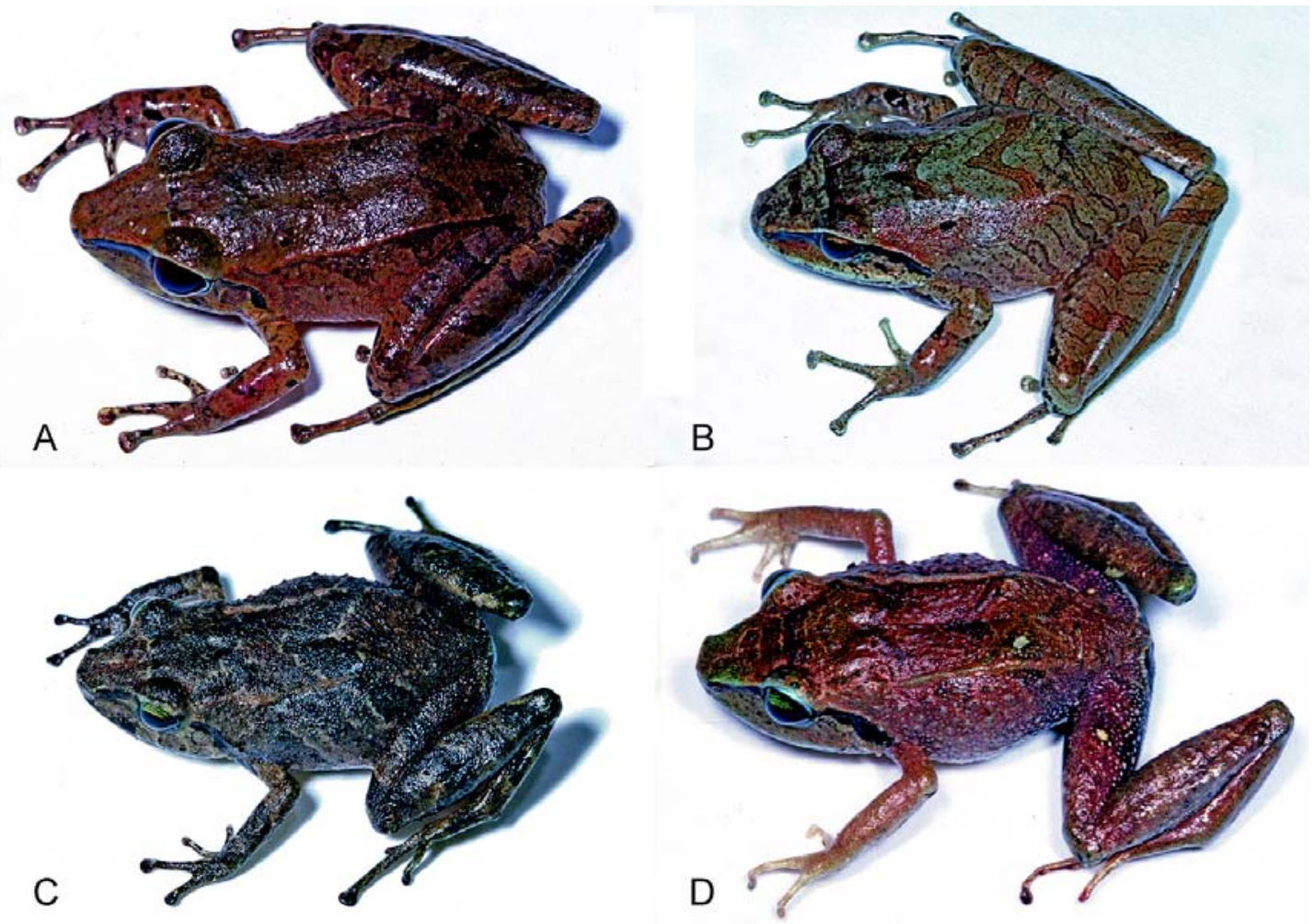

Figure 1 - (A) Pristimantis adiastolus, KU 291681, male, 28.0 mm SVL. (B) Pristimantis bipunctatus, KU 291638, female, 35.5 mm SVL. (C) Pristimantis albertus, KU 291675, female, $20.7 \mathrm{~mm}$ SVL. (D) Pristimantis stictogaster, KU 291659 female, 20.5 mm SVL.

finlike tubercle in the middle of the back of some individuals. Pristimantis meridionalis Lehr and Duellman, 2007, stictogaster, and tanyrhynchus differ from $P$. adiastolus by having pale spots or flecks on the posterior surfaces of the thighs; also, the latter differs by having a conical tubercle on the heel. Pristimantis rhabdolaemus, toftae, and the next species described herein are like $P$. adiastolus in lacking pale markings on the posterior surfaces of the thighs, but $P$. rhadolaemus differs by having a weak dorsolateral fold and having small tubercles on the heel and outer edge of the tarsus, whereas $P$. albertus differs by having brown mottling on the belly and brown flecks on the throat, and $P$. toftae differs by having lateral fringes on the digits and a cream, yellow, or pale orange spot in the groin.

Description of holotype - An adult male with head as wide as body, head width $31.8 \%$ SVL; head length $35.7 \%$ SVL; snout long, narrow, bluntly rounded in dorsal view, nearly truncate in profile, protruding slightly beyond margin of lower lip; eye-nostril distance $97.1 \%$ length of eye; nostrils slightly protuberant, directed laterally at level slightly behind anterior margin of lower lip. Canthus rostralis straight, rounded in section, not elevated; loreal region slightly concave; lips rounded; internarial region slightly depressed; top of head flat; upper eyelid lacking tubercles, its width $70.0 \%$ interorbital distance; 
supratympanic fold barely elevated, curved from posteroventral edge of orbit to point above insertion of arm, barely obscuring upper edge of tympanum; tympanic annulus distinct, smooth; tympanic membrane differentiated, smooth; tympanum nearly round, $57.1 \%$ diameter of eye, separated from eye by distance about two-thirds diameter of tympanum; one enlarged postrictal tubercle. Choanae small, round, not concealed by palatal shelf of maxilla; vomerine odontophores prominent, oblique, widely separated medially, at level between posterior margins of choanae, each process bearing six teeth; tongue twice as long as wide, not notched behind, posterior two-fifths not adherent to floor of mouth; vocal slits short, at midlateral base of tongue.

Skin on dorsum shagreen; skin on flanks finely granular; skin on posteroventral surfaces of thighs granular; skin on belly weakly areolate; other ventral surfaces smooth; dorsolateral fold prominent, originating in scapular region and extending to inguinal region; discoidal fold present; cloacal sheath short; no large tubercles in cloacal region. Ulnar tubercles low, diffuse; thenar tubercle elevated, elliptical, about same size as bifid palmar tubercle; subarticular tubercles small, subconical; few minute supernumerary tubercles on proximal segments of digits; fingers lacking lateral fringes; relative lengths of fingers I < II < IV < III; discs on Fingers III and IV broadly elliptical, about twice width of digit proximal to disc; all fingers having terminal ventral pads well defined by circumferential grooves. Hind limbs slender; when hind limbs flexed perpendicular to axis of body heels overlap by about two-fifths length of shank; tibia length $61.8 \%$ SVL; foot length $54.3 \%$ SVL; heel and outer edge of tarsus lacking tubercles; inner tarsal fold on distal onethird of tarsus; inner metatarsal tubercle elevated, elongately elliptical, about four times size of subconical outer metatarsal tubercle; toes slender, lacking lateral fringes, bearing rounded terminal discs smaller than those on fingers; basal webbing between all toes; relative lengths of toes I $<$ II $<$ III $<$ V $<$ IV; Toe III slightly shorter than Toe V; Toe III extending to base of antepenultimate subarticular tubercle on Toe IV; Toe $\mathrm{V}$ extending to middle of antepenultimate subarticular tubercle on Toe IV; subarticular tubercles small, subconical; supernumerary tubercles absent.

Coloration in preservative - Dorsum of head, body, and limbs reddish brown with no darker pattern except faint brown interorbital bar and pair of small black spots laterally in scapular region at level of arms; dark brown transverse bar on forearm; faint brown diagonal bars on dorsal surfaces of thighs; four brown diagonal bars on each shank; dark brown longitudinal streak on tarsus; anterior and posterior surfaces of thighs uniform reddish brown. Facial markings consisting of dark brown canthal and posteroventrally curved postorbital stripes; upper lip reddish tan with faint brown labial bars. Flanks reddish brown gradually fading into cream belly; throat cream with brown mottling; ventral surfaces of limbs uniform cream.

Coloration in life - The dorsal surfaces and flanks are reddish tan with slightly darker brown markings consisting of an interorbital bar, irregular spots on the body, diagonal marks on the flanks, and diagonal bars on the limbs (Figure 1A). The side of the head and dorsolateral folds are reddish tan. The canthal and postorbital stripes and a pair of small spots in the scapular region are black. The posterior surfaces of the thighs are uniform reddish brown. The ventral surfaces are creamy white with pale brown mottling on the throat. The iris is reddish copper with fine black flecks.

\section{Measurements of the holotype (in $\mathrm{mm}$ ) -} Snout-vent length 28.0, tibia length 17.3 , foot length 15.2, head length 10.0, head width 8.9, interorbital distance 3.0, width of upper eyelid 2.1, internarial distance 3.0, eye-nostril distance 3.4 , diameter of eye 3.5 , diameter of tympanum 2.0. 
Distribution and ecology - This species is known only from lower humid montane forest at an elevation of $1200 \mathrm{~m}$ on the eastern slopes of the Cordillera Yanachaga in central Peru. The holotype was perched on a leaf about $1.5 \mathrm{~m}$ above the ground in riparian forest at night.

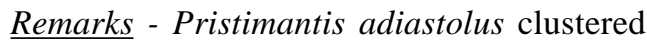
with, but was well separated from, $P$. bipunctatus in a phylogenetic tree based on sequences of the mitochondrial 12S rRNA gene (Duellman and Hedges 2005), reproduced here with updated species names (Figure 2). Although this new species was inadvertently omitted from the more recent phylogenetic analysis (Heinicke et al. 2007), we have added it to the most complete data set available, 344 species of Brachycephalids and "eleutherodactylines” (Hedges et al. 2008) and confirmed its position to be the same as shown here (Figure 2 ) as closest relative to $P$. bipunctatus and with a similarly long branch length separating the two species.

The significance of the morphological differences distinguishing Pristimantis adiastolus and P. bipunctatus must await the collection of additional specimens of both species. However, discordance between genetics and morphology is not uncommon in species of the Pristimantis conspicillatus and peruvianus groups. Most species share a suite of morphological characters (long limbs, long snout, and color pattern of chevrons) that have confused herpetologists for decades. In fact, $P$. conspicillatus and $P$. peruvianus were previously considered to be only weakly separable and possibly conspecific (Lynch 1980); yet sequence analyses show that these two species and the groups they represent are deeply divergent (Heinicke et al. 2007, Hedges et al. 2008).

Other species of anurans at the type locality of Pristimantis adiastolus or within $2 \mathrm{~km}$ of Cacazú (900-1200 m) include Leptodactylus andreae, L. grisegularis, Hypsiboas cinerascens (= Hypsiboas granosus), Rhinella poeppigii,

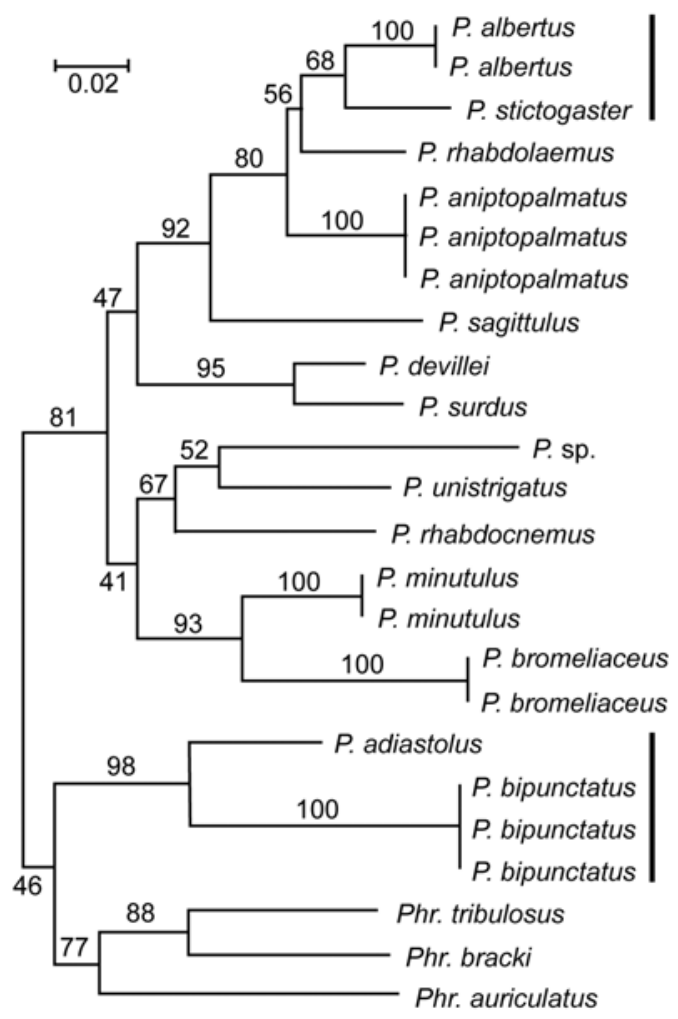

Figure 2 - Relationships of some Peruvian and Ecuadorian species of Pristimantis (P.) and Phrynopus $(P h r$.) shown in a minimum evolution tree derived from sequences of the mitochondrial 12S rRNA gene modified from Duellman and Hedges (2005). Numbers at nodes are bootstrap confidence values. The scale bar indicates percent sequence divergence. Heavy vertical lines indicate pairs of cryptic species.

and another new species of Pristimantis described below.

Pristimantis albertus sp. nov.

(Figure 1C)

Holotype - KU 291675, an adult female, from Río San Alberto, $0.9 \mathrm{~km} \mathrm{~N}, 2.1 \mathrm{~km} \mathrm{E}$ Oxapampa, $1970 \mathrm{~m}, 10^{\circ} 33^{\prime} 36^{\prime \prime S}, 75^{\circ} 24^{\prime} \mathrm{W}$, Departamento Pasco, Peru, obtained on 5 July 1987 by S. Blair Hedges. 
Paratype - KU 291676, an adult female, collected with the holotype.

Etymology - The specific name is a noun in apposition and refers to the type locality, a river named for Saint Albertus, also known as Albertus Magnus, a renowned scientist and teacher of his time (13 ${ }^{\text {th }}$ Century).

Diagnosis - This member of the Pristimantis (Pristimantis) peruvianus Group is characterized by (1) skin on dorsum shagreen with scattered small tubercles; that on venter weakly areolate; discoidal fold absent; dorsolateral folds low, discontinuous; (2) tympanic membrane differentiated; tympanic annulus distinct; (3) snout moderately long, rounded in dorsal view and in profile; (4) upper eyelid lacking tubercles, narrower than interorbital distance; cranial crests absent; (5) dentigerous processes of vomers absent; (6) condition of vocal slits and nuptial pads unknown; (7) Finger I shorter than Finger II; discs on fingers rounded, expanded to about half again width of digit proximal to pad; (8) fingers lacking lateral fringes; (9) ulnar tubercles absent; (10) heel and tarsus lacking tubercles and folds; (11) inner metatarsal tubercle elliptical, about $6 \times$ rounded outer metatarsal tubercle; supernumerary plantar tubercles absent; (12) toes lacking lateral fringes; webbing absent; Toe V slightly longer than Toe III; discs smaller than those on outer fingers; (13) dorsum tan with brown markings; venter cream with brown flecks on throat and mottling on belly; posterior surfaces of thighs brown; (14) SVL unknown in males, 19.7 and $20.7 \mathrm{~mm}$ in two females.

Pristimantis albertus closely resembles $P$. stictogaster structurally, especially in having low dorsolateral folds, which are roughened and discontinuous in $P$. albertus in contrast to smooth and continuous in $P$. stictogaster. The latter species differs from $P$. albertus in having vomerine teeth and in details of colorationposterior surfaces of thighs black with cream flecks and belly bluish white with black spots in $P$. stictogaster in contrast to posterior surfaces of thighs uniform brown and belly creamy white with brown mottling in P. albertus (Figure 1C, D). Other Peruvian members of the Pristimantis conspicillatus and peruvianus groups, both characterized by Toe $\mathrm{V}$ being only slightly longer than Toe III, having dorsolateral folds and areolate skin on the belly, and lacking pale spots or flecks on the posterior surfaces of the thighs include $P$. adiastolus, rhabdolaemus, and toftae. These three species are readily distinguished from $P$. albertus by their ventral coloration-venter cream with brown mottling on throat in $P$. albertus, venter white to pale yellow with brown streaks on throat and brown spots on chest and belly in P. rhabdolaemus, pale cream venter with median longitudinal black stripe on throat in P. toftae.

Description of holotype - An adult female with head as wide as body, head width $33.8 \%$ SVL; head length $36.2 \%$ SVL; snout moderately long, rounded in dorsal view and in profile, not protruding beyond margin of lower lip; eyenostril distance $92.0 \%$ length of eye; nostrils slightly protuberant, directed laterally at level slightly behind anterior margin of lower lip. Canthus rostralis shallowly curved, rounded in section, not elevated; loreal region slightly concave; lips rounded; internarial region slightly depressed; top of head flat; upper eyelid lacking tubercles, its width 56.5\% interorbital distance; supratympanic fold barely elevated, angling posteroventrally from posterior edge of orbit to point above insertion of arm, barely obscuring posterodorsal edge of tympanum; tympanic annulus distinct smooth; tympanic membrane differentiated, smooth; tympanum nearly round, $56.0 \%$ diameter of eye, separated from eye by distance equal to about two-thirds diameter of tympanum; two enlarged postrictal tubercles. Choanae small, round, not concealed by palatal shelf of maxilla; vomerine odontophores absent; tongue twice as long as wide, notched behind, posterior one-half not adherent to floor of mouth.

Skin on dorsum shagreen with scattered small tubercles, especially posteriorly; skin on 
flanks finely spiculate; skin on belly weakly areolate; other ventral surfaces smooth; dorsolateral folds low, glandular, originating in scapular region and extending to sacrum; discoidal fold present; cloacal sheath short; no large tubercles in cloacal region. Ulnar tubercles absent; thenar tubercle elliptical, about same size as bifid palmar tubercle; subarticular tubercles small, round; few minute supernumerary tubercles on proximal segments of digits; fingers lacking lateral fringes; relative lengths of fingers I $<$ II $<$ IV $<$ III; discs on Fingers III and IV expanded laterally, rounded, about half again width of digit proximal to disc; all fingers having ventral pads well defined by circumferential grooves. Hind limbs slender; when hind limbs flexed perpendicular to axis of body heels overlap by about one-fifth length of shank; tibia length 53.1\% SVL; foot length $43.0 \%$ SVL; heel and outer edge of tarsus lacking tubercles; inner tarsal fold absent; inner metatarsal tubercle elevated, elliptical, about six times size of rounded outer metatarsal tubercle; toes slender, lacking lateral fringes, bearing rounded terminal discs smaller than those on fingers; webbing absent; relative lengths of toes I $<$ II $<$ III $<$ V $<$ IV; Toe III slightly shorter than Toe V; Toe III not quite extending to base of antepenultimate subarticular tubercle on Toe IV; Toe V extending to middle of antepenultimate subarticular tubercle on Toe IV; subarticular tubercles small, round; supernumerary tubercles absent.

Coloration in preservative - Dorsum of head, body, and limbs tan with faint brown interorbital bar, brown interrupted $\mathrm{W}$-shaped mark in scapular region, faint brown chevron on back at midlength of body; dark brown transverse bar on forearm; brown spots on dorsal surfaces of thighs; three brown diagonal bars on each shank, one on each tarsus; anterior and posterior surfaces of thighs uniform brown. Facial markings consisting of dark brown canthal and posteroventrally curved postorbital stripes and two faint brown labial bars. Flanks tan with small dark brown irregular marks; throat chest and belly cream with brown mottling on belly and brown flecks on throat; ventral surfaces of limbs uniform tan.

Coloration in life - All dorsal surfaces are brown with darker brown markings consisting of interobital bar with cream anterior margin and diffuse posteromedial extension, irregular and interrupted W-shaped mark in scapular region, a broad chevron-shaped mark at midlength of the body, and small brown postsacral marks (Figure 1C). There are dark brown diagonal bars on the hindlimbs and a broad transverse brown mark on each forearm. Dark brown canthal and postorbital stripes are present, and the labial bars are faintly darker brown than the rest of the lip. The flanks are brown with small dark brown marks. The anterior and posterior surfaces of the thighs are brown. The throat and belly are cream with minute brown flecks on the former and brown mottling on the latter. The iris is greenish gold with fine black reticulations.

Measurements of holotype (in $\mathrm{mm}$ ) - The measurements of the female holotype are followed by those of the female paratype. Snoutvent length 20.7, 19.7; tibia length 11.0, 9.9; foot length 8.9, 8.4; head length 7.5, 7.4; head width 7.0. 7.0; interorbital distance 2.3, 2.2; width of upper eyelid 1.3, 1.3; internarial distance 2.3, 2.2; eye-nostril distance 2.3, 2.1; diameter of eye $2.5,2.3$; diameter of tympanum 1.4, 1.4 .

Distribution and ecology - The species is known only from the type locality, where the two known individuals were found in leaf litter in humid montane forest.

Remarks - In the phylogenetic analysis of molecular data presented by Duellman and Hedges (2005), reproduced here (Figure 2), Pristimantis albertus is the closest relative of $P$. stictogaster, another member of the Pristimantis peruvianus Group known from elevations of 
1470-2790 m in the Cordillera Yanachaga (see comment below in Discussion concerning elevational range). The female (KU 291676) paratype with a SVL of $19.7 \mathrm{~mm}$ contained 16 unpigmented ovarian eggs. One apparently undescribed species of hylid frog (Scinax) and two other species of Pristimantis ( $P$. cruciocularis and $P$. sagittulus) also were collected at the type locality.

\section{Pristimantis minutulus sp. nov.}

(Figure $3 \mathrm{~A}, \mathrm{~B}$ )

Holotype - KU 291678, an adult female, from 0.0-1.5 km NW Cacazú, 900-1200 m, 10³8'S, $75^{\circ} 07^{\prime} \mathrm{W}$, Departamento Pasco, Peru, obtained on 8 July 1987 by S. Blair Hedges.

Paratypes - KU 291677, female, and 291679-80, 308608, males, collected with the holotype.

Etymology - The specific name is the diminutive of the Latin minutus meaning small and is used in reference to the small size of this species.

Diagnosis - This member of the Pristimantis (Pristimantis) unistrigatus Group is characterized by (1) skin on dorsum smooth; that on venter weakly areolate; discoidal fold not evident; dorsolateral folds absent; (2) tympanic membrane not differentiated; tympanic annulus absent; (3) snout moderately long, rounded in dorsal view and in profile; (4) upper eyelid lacking tubercles, narrower than interorbital distance; cranial crests absent; (5) dentigerous processes of vomers absent; (6) vocal slits and nuptial pads absent; (7) Finger I shorter than II; discs on fingers rounded, about half again width of digit proximal to pad; (8) fingers lacking lateral fringes; (9) ulnar tubercles absent; (10) heel and tarsus lacking tubercles and folds; (11) inner metatarsal tubercle ovoid, about $3 \times$ rounded outer metatarsal tubercle; supernumerary plantar tubercles absent; (12) toes lacking lateral fringes; webbing absent; Toe V much longer than Toe III; discs smaller than those on outer fingers; (13) dorsum tan with brown markings; venter cream with brown flecks; (14) SVL 13.1-15.2 mm in three males, $17.0-20.0 \mathrm{~mm}$ in two females.

Pristimantis minutulus is one of eight species of Pristimantis in the Cordillera Oriental of Peru that lacks a differentiated tympanic membrane and annulus. Among the others, $P$. ventrimarmoratus (Boulenger, 1912) is much larger (SVL in males to $25.5 \mathrm{~mm}$, in females to $43.3 \mathrm{~mm}$ ) and has bold black mottling on a white belly. Of the other small species, $P$. cruciocularis, flavobracatus, lirellus (Dwyer 1995), and vilcabambae differ from P. minutulus by having tubercles on the upper eyelids and heels (absent in P. minutulus). Pristimantis rhabdocnemus and the primarily lowland $P$. martiae (Lynch 1974) differ from P. minutulus in having tubercles on the heels and lateral fringes on the digits (both absent in $P$. minutulus); furthermore, $P$. martiae and $P$. minutulus differ in coloration-gray venter and tan groin with diagonal brown bars in $P$. martiae, in contrast to cream venter and large cream (in preservative) spot in the groin in $P$. minutulus. Moreover, $P$. rhabdocnemus differs from $P$. minutulus by having the skin on the dorsum shagreen and having a tubercle on the heel.

Description of holotype - Head as wide as body, head width $35.3 \%$ SVL; head length $39.4 \%$ SVL; snout moderately long, rounded in dorsal view and in profile, protruding slightly beyond margin of lower lip; eye-nostril distance $90.3 \%$ length of eye; nostrils slightly protuberant, directed laterally at level just behind anterior margin of lower lip. Canthus rostralis nearly straight, broadly rounded in section, not elevated; loreal region slightly concave; lips rounded; internarial region barely depressed; top of head slightly convex; upper eyelid lacking tubercles, its width $75.0 \%$ interorbital distance; supratympanic fold not evident; tympanic membrane differentiated; 


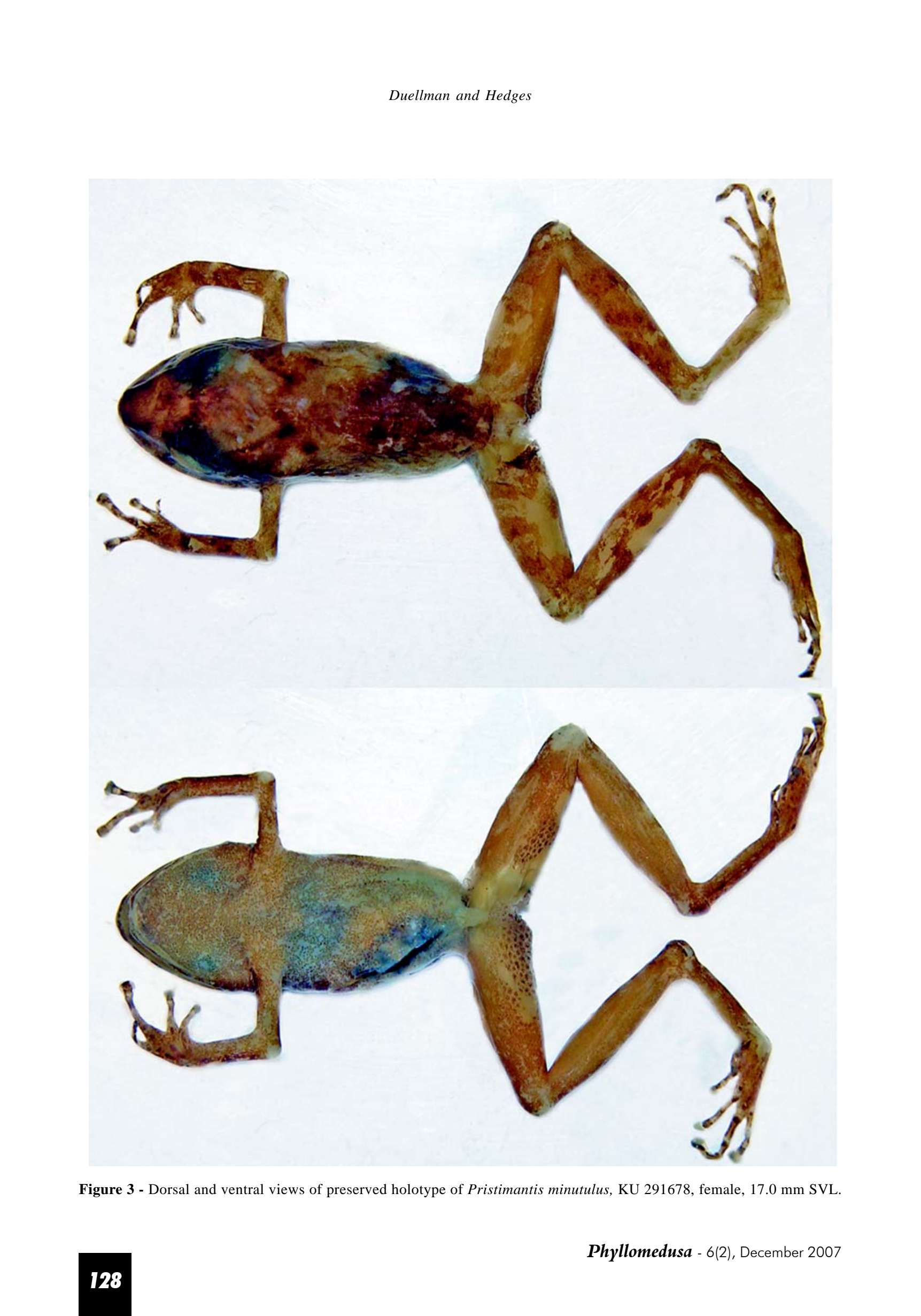


tympanic annulus absent; enlarged postrictal tubercles absent. Choanae small, round, not concealed by palatal shelf of maxilla; vomerine odontophores absent; tongue cordiform, slightly longer than wide, shallowly notched behind, posterior two-fifths not adherent to floor of mouth.

Skin on dorsum smooth with a few small tubercles posteriorly on body; skin on flanks smooth; skin on belly weakly areolate; other ventral surfaces smooth; dorsolateral folds absent; discoidal fold not evident; cloacal sheath short; no large tubercles in cloacal region. Ulnar tubercles absent; thenar tubercle small, elliptical, slightly larger than rounded palmar tubercle; subarticular tubercles small, rounded; supernumerary tubercles low, small, only on proximal segments of digits; fingers lacking lateral fringes; relative lengths of fingers I $<$ II $<$ IV < III; discs on Fingers III and IV rounded, about half again width of digit proximal to disc; all fingers having ventral pads well defined by circumferential grooves. Hind limbs slender; when hind limbs flexed perpendicular to axis of body heels overlap by about one-fourth length of shank; tibia length $56.5 \%$ SVL; foot length $40.0 \%$ SVL; heel and outer edge of tarsus lacking tubercles; inner tarsal fold absent; inner metatarsal tubercle ovoid, about three times size of rounded outer metatarsal tubercle; toes slender, lacking lateral fringes, bearing rounded terminal discs smaller than those on fingers; webbing absent; relative lengths of toes I $<$ II $<$ III $<$ V $<$ IV; Toe III much shorter than Toe V; Toe III extending to base of antepenultimate subarticular tubercle on Toe IV; Toe V extending beyond distal margin of antepenultimate subarticular tubercle on Toe IV; subarticular tubercles small, round; supermumerary tubercles absent.

Coloration in preservative - Dorsum of head, body, and limbs tan with brown markings consisting of square blotch on snout, interorbital bar, triangular (apex dorsal) labial bars, Wshaped mark in scapular region, large blotch in sacral region extending to vent, two transverse bars on each forearm, and three diagonal bars on each thigh and shank; flanks tan with large, ovoid, white blotch in groin; anterior and posterior surfaces of thighs brown; throat, chest, and belly cream with many minute brown flecks; ventral surfaces of hind limbs tan.

Coloration in life - Color notes were taken on a dead and slightly decomposed but unpreserved specimen (KU 308608). The dorsal surfaces appear to be brownish gray, but on close inspection minute iridescent green, red, and blue flecks are visible; generally these are mixed, but in some places there are small concentrations of red flecks. There are orangetan middorsal blotches on the snout; there are two grayish white vertical bars below each eye and two similar bars in the loreal region. There are one or two large yellowish orange blotches on the posterior part of the flanks anterior to the groin. The anterior and posterior surfaces of the thighs are brownish gray; markings are absent on the posterior surfaces, but there are faint pale bars on the anterior surfaces. The venter is gray with a profusion of unevenly distributed brown flecks. The iris appears to be dark gray.

Measurement of holotype (in $\mathrm{mm}$ ) - Snoutvent length 17.0, tibia length 9.6, foot length 6.8 , head length 6.7 , head width 6.0 , interorbital distance 2.0, width of upper eyelid 1.5, internarial distance 1.5, eye-nostril distance 1.9, diameter of eye 2.1.

Distribution and ecology - This species is known only from humid lower montane forest in the vicinity of the type locality at elevations of 900-1200 m on the lower Amazonian slopes of the Cordillera Yanachaga in central Peru. All individuals were on leaves $30-60 \mathrm{~cm}$ above the ground at night.

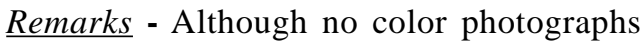
were taken of the living frogs, a specimen (KU 308608) that had died after collection was 
frozen whole and provided us with data on coloration. Other species with colored spots in the groin are Pristimantis cruciocularis (reddish orange spots) and P. flavobracatus (yellow spots) (Lehr et al. 2006), but these two species differ in other ways from $P$. minutulus. Other species of anurans at the type locality of $P$. minutulus or within $2 \mathrm{~km}$ of Cacazú include Leptodactylus andreae, L. grisegularis, Pristimantis adiastolus, Hypsiboas cinerascens (= Hypsiboas granosus), and Rhinella poeppigii.

Pristimantis minutulus clustered with, but was well separated from, $P$. bromeliaceus in a phylogenetic tree of a small number of taxa based on the mitochondrial 12S rRNA gene (Duellman and Hedges 2005) (Figure 2). When it was included in a much larger data analysis of 344 species (Hedges et al. 2008), it clustered most closely with P. ardalonychus (Pristimantis unistrigatus Group), a species known only from the Amazonian slopes of the Cordillera Central in northern Peru, and slightly more distantly with P. ockendeni (Pristimantis frater Group). In terms of genetic divergence (branch length) it was not especially close to either of those species. As shown and discussed elsewhere (Hedges et al. 2008), many species groups of the subgenus Pristimantis are not monophyletic and are in need of revision in the future when additional sequence data become available. Until then we tentatively assign $P$. minutulus to the Pristimantis unistrigatus Group.

\section{Discussion}

As noted by Duellman and Hedges (2005), sequence analysis was used originally as a forensic tool in sorting and allocating specimens to species; the molecular data showed the existence of species that probably would not have been identified as such using only morphological characters. Thus, pairs of cryptic species were discovered-(1) Pristimantis adiastolus and $P$. bipunctatus, and (2) $P$. albertus and $P$. stictogaster (Figure 2). The origins of these pairs of closely related species are unknown. However, in both cases the members of each pair seem to be separated by elevation. Pristimantis adiastolus is known only from $1200 \mathrm{~m}$, whereas the sister species, $P$. bipunctatus ranges from 1530 to $2320 \mathrm{~m}$; $P$. albertus is known only from $1700 \mathrm{~m}$, well below the known confirmed distribution of its closest relative, $P$. stictogaster, at 2600-2790 m. (Lehr et al.'s [2006] report of $P$. stictogaster from $1470 \mathrm{~m}$ possibly is based on a specimen of $P$. albertus; its identity needs to be confirmed.) The known differences in elevation suggest that there may be habitat differences between the members of species pairs; adequate climatic data are not available, but certainly there are temperature differences between the known ranges of $P$. albertus and $P$. stictogaster.

Habitat differences exist between cryptic species of Pristimantis in southern Peru and adjacent Bolivia; Padial and De la Riva (in press) identified two pairs of cryptic species based on bioacoustic and molecular data. A member of one pair, $P$. fenestratus, is widespread in humid Amazonian forest, whereas its closest relative, a new species described therein, inhabits drier valleys on the slopes of the Andes. Within the other pair, another new species is widespread in the Amazon lowlands, whereas its closest relative, $P$. danae, has a parapatric distribution on the Amazonian slopes of the Andes.

Unfortunately, we do not have behavior data (e.g., recordings of advertisement calls) for the pairs of cryptic species in the Cordillera Yanachaga; we anticipate that the calls will substantiate the specific differences evident from the molecular data, as do those for the species pairs identified by Padial and De la Riva (in press). As tissues and recordings of advertisement calls become available for many Andean species of Pristimantis, we expect that many more cryptic species will be identified. Certainly on the Amazonian slopes of the Cordillera Oriental in central Peru, $P$. mendax and $P$. platydactylus are likely candidates to 
Table 1 - Elevational distributions of “eleutherodactylid” frogs in the vicinity of the Cordillera Yanachaga, Departamento de Pasco, Peru. Under habitat, HMF = humid montane forest, PU = puna. Species lacking a tympanum are noted by an asterisk (*).

\begin{tabular}{|c|c|c|}
\hline Species & Elevation (m) & Habitat \\
\hline “Eleutherodactylus” lundbergi & $1800-2760$ & HMF \\
\hline Phrynopus A & 2600 & HMF \\
\hline Phrynopus B* & 2600 & HMF \\
\hline Phrynopus C* & 3363 & HMF \\
\hline Phrynopus D* & 3589 & $\mathrm{PU}$ \\
\hline Phrynopus bracki* & $2200-2600$ & HMF \\
\hline Phrynopus bufoides* & $3650-4100$ & PU \\
\hline Phrynopus paucari* & 3600 & PU \\
\hline Phrynopus pesantesi* & $4280-4390$ & PU \\
\hline Phyllonastes duellmani* & 2900 & HMF \\
\hline Pristimantis adiastolus & 1200 & $\mathrm{HMF}$ \\
\hline Pristimantis albertus & 1700 & HMF \\
\hline Pristimantis aniptopalmatus & $2300-2600$ & HMF \\
\hline Pristimantis bipunctatus & $1530-2320$ & HMF \\
\hline Pristimantis bromeliaceus & $2200-2790$ & HMF \\
\hline Pristimantis cruciocularis* & $1610-1790$ & $\mathrm{HMF}$ \\
\hline Pristimantis flavobracatus* & 1770 & $\mathrm{HMF}$ \\
\hline Pristimantis A* & 2790 & HMF \\
\hline Pristimantis mendax & 2479-3000 & HMF \\
\hline Pristimantis minutulus* & $900-1200$ & HMF \\
\hline Pristimantis ockendeni & $2600-2790 *$ & HMF \\
\hline Pristimantis ornatus & $2400-3000$ & $\mathrm{HMF}$ \\
\hline Pristimantis pardalinus & 2640 & HMF \\
\hline Pristimantis peruvianus & $2050 *$ & HMF \\
\hline Pristimantis platydactylus & $2540-3275$ & HMF, PU \\
\hline Pristimantis rhabdocnemus* & $930-2600$ & HMF \\
\hline Pristimantis sagittulus & $1970-2200$ & $\mathrm{HMF}$ \\
\hline Pristimantis stictogaster & $2600-2790$ & HMF \\
\hline Pristimantis ventrimarmoratus* & $970-1100 *$ & HMF \\
\hline
\end{tabular}

* Also occurs at low elevations in the Amazon Basin. Phrynopus A and B are being named by Duellman and Hedges (in press); Phrynopus C and D are being named by Chaparro et al. (in press), and Pristimantis A is being named by Boano et al. (in press). 
contain cryptic species, because both have comparatively broad geographical and elevational ranges. Similarly, species that inhabit the Amazonian lowlands and the slopes of the Andes (e.g., P. altamazonicus, ockendeni, and peruvianus) are likely to be composites of cryptic species.

A rather narrow swath through the Cordillera Oriental in central Peru at elevations of 1000 $4400 \mathrm{~m}$ shows the existence of 29 species of "eleutherodactyline" frogs (Table 1). This tabulation differs from that by Lehr et al. (2006), who included a much broader area and did not include eight species named herein, by Boano et al. (in press), Chaparro et al. (in press), and Duellman and Hedges (in press). It is evident that most species inhabit the humid montane forests on the Andean slopes; only one species of Pristimantis (P. playdactylus) ascends into the puna-the grassland above tree line dominated by the grass (Stipa sp.) The puna also is inhabited by four species of Phrynopus (Chaparro et al. in press) whereas three others are at least partially sympatric in humid montane forest (Duellman and Hedges in press); one of these, $P$. bracki, descends to $2200 \mathrm{~m}$, the lowest known elevation for the genus.

Within the humid montane forest, species diversity is highest at 2300-2600 m (12 species) and at 2600-2900 $\mathrm{m}$ (13 species), whereas at elevations above $2900 \mathrm{~m}$ only three species of Pristimantis and five of Phrynopus have been found. These elevations must be regarded as tentative inasmuch as future surveys in the Cordillera Yanachaga certainly will result in wider ranges for many of the species.

Lehr et al. (2006) pointed out an altitudinal trend in the absence of a tympanum in "eleutherodactyline" frogs in central Peru. As shown in Table 1, 14 of the 29 species in our transect lack a differentiated tympanum. Within this transect from the lower Andean slopes to the upper reaches of anuran habitation absence of a tympanum seems to be most common at higher elevations. However, this apparent trend is influenced by the diversity of Phrynopus at the highest elevation; of the 21 known species of Phrynopus only two species have a differentiated tympanic membrane, and one of these occurs at one of the lowest known elevations $(2600 \mathrm{~m})$ for the genus (Duellman and Hedges in press). Among the species of Pristimantis included in the transect, each of the three that range upward to $3000 \mathrm{~m}$ or more $(P$. mendax, ornatus, and platydactylus) have a tympanum, whereas the species with the lowest elevational range ( $P$. ventrimarmoratus) lacks a tympanum. In addition to the latter, six other species of Pristimantis (P. altmazonicus, croceoinguinis, imitatrix, martiae, quaquaversus, and tantanti) in Amazonian Peru lack a differentiated tympanic membrane. In contrast, many Peruvian species of the Pristimantis orestes Group ( $P$. atrabracus, corrugatus, melanogaster, pinguis, and stictoboubonus) living at elevations of 3000-3900 m have well-defined tympana (Duellman and Pramuk 1999, Duellman et al. 2006). Thus, within Peruvian Pristimantis, there is no altitudinal trend in the absence of a tympanum.

Sympatry is not at all uncommon among Andean species of Pristimantis. In the Cordillera Yanachaga, four species (P. aniptopalmatus, bromeliaceus, rhabdocnemus, and stictogaster) occur sympatrically at $2600 \mathrm{~m}$. This is about the usual number of Pristimantis found in humid montane forests throughout Peru-five species each at $1800 \mathrm{~m}$ on the Amazon slopes of the Cordillera Oriental and at 1138 and $1750 \mathrm{~m}$ on the eastern slopes of the Cordillera del Cóndor (Duellman and Pramuk 1999), five species At $1800 \mathrm{~m}$ on the western slopes of the Cordillera de Huancabamba (Duellman and Wild 1993), and six species each at $1800 \mathrm{~m}$ on the Río Zaña in Cajamarca (Duellman and Lehr 2007) and at $1700 \mathrm{~m}$ on the Río Cosñipata in Cusco (Duellman 1978a). However, the locality at $2600 \mathrm{~m}$ in the Cordillera Yanachaga also has three species of Phrynopus, thereby bringing to eight the total number of species of "eleutherodactyline" frogs at that locality. Ten of these species from the 
Cordillera Yanachaga were first collected by SBH during a two-week period in 1987, during the dry season when no frogs were calling and only a few specimens of each species were found. Recent collections in the region are increasing the number of species.

The numbers of species of "eleutherodactyline” frogs at various elevations in humid montane forests on the Andean slopes in Peru correspond to the numbers (6-11) of species at six localities at elevations of $1150-2660 \mathrm{~m}$ on the Amazonian slopes of the Andes in Ecuador (Lynch and Duellman 1980) but are lower than the numbers (6-16) of species at seven localities on the Pacific slopes in Ecuador (Lynch and Duellman 1997). These are more like the numbers found on the Pacific lowlands of Ecuador (11 at Río Palenque and 13 at Santo Domingo de los Colorados; Lynch and Duellman 1997) and 17 at Santa Cecilia in Amazonian Ecuador (Duellman 1978d). These data agree with Lynch et al. (1997) that the greatest richness of "eleutherodactylines" is in the humid Chocoan Region of northwestern South America.

\section{Acknowledgements}

WED thanks O. Aguilar and J. C. Chaparro for providing access to specimens at the Museo de Historia Natural, Universidad Nacional de San Antonio de Abad del Cusco and to C. Aguilar and K. S. Ting for providing working space in the Museo de Historia Natural at the Universidad Nacional Mayor San Marcos in Lima. Some material from various collections was made available for study by E. Lehr while he was supported by a Humboldt Fellowship at the University of Kansas. SBH thanks L. Rodríguez for suggesting the Cordillera Yanachaga for a collecting site; A. Brack, C. Brack, and W. Brack for hospitality and logistical support; P. Aguilar and L. Vajda for assistance in the field; and N. Carrillo de Espinoza, B. A. Luscombe, V. Morales, and A. Salas for logistical assistance in Lima. The collecting permit (048-87) and export permit (284) were obtained from the Dirección General Forestal y de Fauna of Peru. We are grateful to J. C. Chaparro and I. De la Riva for their critical reviews of the manuscript. We thank Juan Manuel Guayasamin for translating the resumen and Edgar Lehr for the images in figure 3.

\section{References}

Anonymous (1987) Guidelines for the use of amphibians and reptiles in field research. American Society of Ichthyologists and Herpetologists, Herpetologists' League, Society for the Study of Amphibians and Reptiles. 14 pp.

Boano, G., S. Mazzotti and R. Sindaco. In press. A new peculiar species of Pristimantis (Anura: Leptodactylidae: Eleutherodactylinae) from YanachagaChemillén National Park, Peru. Zootaxa.

Chaparro, J. C., J. M. Padial and I. De la Riva. In press. Two sympatric new species of Phrynopus (Anura: Brachycephalidae) from Yanachaga Chemillén National Park (central Peruvian Andes). Zootaxa.

Duellman, W. E. 1978a. New species of leptodactylid frogs of the genus Eleutherodactylus from the Cosñipata Valley, Perú. Proceedings of the Biological Society of Washington 91: 418-430.

Duellman, W. E. 1978b. Three new species of Eleutherodactylus from Amazonian Peru (Amphibia: Anura: Leptodactylidae). Herpetologica 34: 264-270.

Duellman, W. E. 1978c. Two new species of Eleutherodactylus (Anura: Leptodactylidae) from the Peruvian Andes. Transactions of the Kansas Academy of Science 81: 65-71.

Duellman, W. E. 1978d. The biology of an equatorial herpetofauna in Amazonian Ecuador. Miscellaneous Publication of the Museum of Natural History, University of Kansas 65: 1-352.

Duellman, W. E. and S. B. Hedges. 2005. Eleutherodactyline frogs (Anura: Leptodactylidae) from the Cordillera Yanachaga in central Peru. Copeia 2005: 526-538.

Duellman, W. E. and S. B. Hedges. In press. Two new minute species of Phrynopus (Anura: Strabomantidae) from the Cordillera Oriental in Peru. Zootaxa.

Duellman, W. E. and E. Lehr. 2007. Frogs of the genus Eleutherodactylus (Leptodactylidae) in the Cordillera Occidental in Peru with descriptions of three new species. Scientific Papers Natural History Museum University of Kansas 39: 1-13. 
Duellman, W. E. and J. B. Pramuk. 1999. Frogs of the genus Eleutherodactylus (Anura: Leptodactylidae) in the Andes of northern Peru. Scientific Papers Natural History Museum University of Kansas 13: 1-78.

Duellman, W. E. and E. R. Wild. 1993. Anuran amphibians from the Cordillera de Huancabamba, northern Peru: systematics, ecology, and biogeography. Occasional Papers of the Museum of Natural History, University of Kansas 157: 1-53.

Duellman, W. E., E. Lehr and P. J. Venegas. 2006. Two new species of Eleutherodactylus (Anura: Leptodactylidae) from the Andes of northern Peru. Zootaxa 1285: 5164.

Hedges, S. B. 1990. A new species of Phrynopus (Anura: Leptodactylidae) from Peru. Copeia 1990: 108-112.

Hedges, S. B., W. E. Duellman and M. P. Heinicke. 2008. New World direct-developing frogs (Anura: Terrarana): molecular phylogeny, classification, biogeography, and conservation. Zootaxa. In press.

Heinicke, M. P., W. E. Duellman and S. B. Hedges. 2007. Major Caribbean and Central American frog faunas originated by ancient oceanic dispersal. Proceedings of the National Academy of Sciences 104: 10092-97.

Lehr, E. 2007. New eleutherodactyline frogs (Leptodactylidae: Pristimantis, Phrynopus) from Peru. Bulletin of the Museum of Comparative Zoology 159: 145-178.

Lehr, E., C. Aguilar and W. E. Duellman. 2004. A striking new species of Eleutherodactylus from Andean Peru (Anura: Leptodactylidae). Herpetologica 60: 275-280.

Lehr, E., M. Lundberg C. Aguilar, and R. von May. 2006. New species of Eleutherodactylus (Anura: Leptodactylidae) from the eastern Andes of Central Peru with comments on central Peruvian Eleutherodactylus. Herpetological Monographs 20: 105-128.
Leviton, A. E., R. H. Gibbs, Jr., E. Heal, and C. E. Dawson. 1985. Standards in herpetology and ichthyology: Part 1. Standard symbolic codes for institutional resource collections in herpetology and ichthyology. Copeia 1985: 802-832.

Lynch, J. D. 1979. Leptodactylid frogs of the genus Eleutherodactylus from the Andes of southern Ecuador. Miscellaneous Publications of the Museum of Natural History, University of Kansas 66: 1-62.

Lynch, J. D. 1980. A taxonomic and distributional synopsis of the Amazonian frogs of the genus Eleutherodactylus. American Museum Novitates 2696: 1-24.

Lynch, J. D. and W. E. Duellman. 1980. The Eleutherodactylus of the Amazonian slopes of the Ecuadorian Andes (Anura: Leptodactylidae). Miscellaneous Publications of the Museum of Natural History, University of Kansas 69: 1-86.

Lynch, J. D. and W. E. Duellman. 1997. Frogs of the genus Eleutherodactylus in western Ecuador: systematics, ecology, and biogeography. Special Publication Natural History Museum University of Kansas 23: 1236.

Lynch, J. D., P. M. Ruiz-Carranza and M. C. ArdilaRobayo. 1997. Biogeographic patterns of Colombian frogs and toads. Revista de la Academia Colombiana de Ciencias Exactas, Físicas y Naturales 21: 237248.

Padial, J. M. and I. De la Riva. In press. Integrative taxonomy reveals cryptic Amazonian species of Pristimantis (Anura). Zoological Journal of the Linnean Society.

Padial, J. M., R. McDiarmid and I. De la Riva. 2006. Distribution and morphological variation of Eleutherodactylus mercedesae Lynch and McDiarmid, 1987 (Amphibia, Anura, Leptodactylidae) with first record for Peru. Zootaxa 1278: 49-56.

\section{Appendix I - Additional Specimens Examined}

Pristimantis avicuporum - PERU: Amazonas: West slope Cordillera Colán, $12 \mathrm{~km}$ (by trail) E La Peca, $1700 \mathrm{~m}$, KU 288628, LSUMZ 39359, 39365 (holotype), 39366-68, 39370-72, 39374-75, 45089; 20 km (by trail) east of La Peca, 1850 m, LSUMZ 52545; West slope Cordillera Colán, 2030 m, LSUMZ 39361. No specific locality: LUSMZ 39348-49, 39351-53, 39367.
Pristimantis bipunctatus - PERU: HUÁNUCO: Dantas, MUSM 11315, 11317-39; 11357-62. Cordillera Azul, \pm 30 km NE Tingo María, 1330 m, AMNH 91566-75; Divisoria, AMNH 8649697, 91558-65. Junín: 11 km [by road] SW San Ramón, 1240 m, MUSM 617-19. PAsco: Km 24 road from Oxapampa to Yaupi, $1530 \mathrm{~m}$, MUSM 19827-31, 19885, MTD 45694-97; Km 85.2 (near Milagro) road from Paucartambo to Yaupi, 
1800 m, MUSM 18014, 18019, 18021; 1 km SE La Suiza (SW of Oxapampa), $2060 \mathrm{~m}, \mathrm{KU}$ 291644-45; $0.7 \mathrm{~km} \mathrm{S,} 4.5 \mathrm{~km}$ [airline] E Oxapampa, 2120 m, KU 291638 (holotype), 291639-43; 10 km ESE Oxapampa, $1610 \mathrm{~m}$, MUSM 20576.

Pristimantis cruciocularis - PERU: PASCO: Río San Alberto, $0.9 \mathrm{~km} \mathrm{~N}, 2.1 \mathrm{~km} \mathrm{E}$ Oxapampa, 1970 m, KU 291673.

Pristimantis lirellus - PERU: HUÁnUCO: Río Llullapichis, 4-5 km upstream from Río Pachitea, 200 m, KU 171893-94. SAN Martín: West slope Abra Tangarana, 7 km [by road] NW San Juan Pacaysapa, 1080 m, KU 212240 (holotype), 212241-59; Pongo de Shilcayo, ca. 4 km NNW Tarapoto, 470 m, KU 212260-63; Río Cerranayacu, 76 km [by road] NW Rioja, 1200 m, KU 212226-39.

Pristimantis martiae - PERU: LORETO: San Jacinto, 175 m, KU 222016; 1.5 km N Teniente López, 310 m, KU 222014-15.

Pristimantis meridionalis - PERU: ANCASH: Caraz, MUSM 0568 (holotype).

Pristimantis rhabdolaemus - PERU: Ayacucho: Huanhuachayocc, Tambo-Valle del Apurimac trail, $1650 \mathrm{~m}$, KU 175082-84, LSUMZ 26150 (holotype), 26151, 26153-54; between Mitupucuru and Estera Ruanda, Tambo-Valle del Apurimac trail, 2400 m, KU 175084; Río Santa Rosa between Pataccocha and San José, 1000 m, LSUMZ 26147-48, 26158, 26254.

Pristimantis sagittulus - PERU: PAsco: Bosque Castilla between Villa Rica and Oxapampa, MUSM 11189; Cordillera Yanachaga, Parque Nacional YanachagaChemillén, MUSM 24470; Río San Alberto, 0.9 km N, 2.1 km E Oxараmpa, 1970 m, KU
291635-36; Refugio Cedro, Parque Nacional Yanachaga-Chemillén, MHNC 4107, 4110; San Alberto, Provincia de Oxapampa, 2200 m, KU 291549, 291575-76, MUSM 18661 (holotype), 18662-63, 20627-29, MTD 45147-49, 4520709, 45213; Santa Cruz, ca. 9 km SSE Oxapampa, 2050 m, KU 206098-100.

Pristimantis skydmainos - PERU: AMAzonAs: Alva, MCZ 89075, 89075 (holotype of Eleutherodactylus karcharias), 89076-80. Madre de Dios: Cocha Cachu, Río Manu, KU 220920, MCZ 88304 (holotype), 88305-09.

Pristimantis stictogaster - PERU: PAsco: Abra Esperanza, Parque Nacional YanachagaChemillén, 2790 m, MHNC 6546, 6555; Cordillera Yanachaga, Parque Nacional Yanachaga-Chemillén, MUSM 24458-69; María Téresa, 1470 m, MTD 46474; 2.9 km N, $9 \mathrm{~km}$ E [airline] Oxapampa, $2600 \mathrm{~m}$, KU 291659 (holotype).

Pristimantis toftae - PERU: Cusco: ca. 40 km SE Quincemil on road to Puerto Maldonado, above Río Marcapata, KU 196477-78, LSUMZ 32296-99. Huánuco: Finca Panguana, Río Llullapichis, 4-5 km upstream from Río Pachitea, 200 m, KU 154806-19, 171852-62, 171863 (holotype), 171864-66, 189236-38. Madre de Dios: Cocha Cachu, Río Manu, KU 154830-34; Cusco Amazónico, 15 km E Puerto Maldonado, 200 m, KU 205095-108, 205117, 205136, 207718-31, 209176 (C\&S), 20917781, 209957, 215489-503, 215748, 220158-59; Manu, 365 m, KU 154820-29.

Pristimantis ventrimarmoratus - PERU: HuÁnuco: Finca Panguana, Río Llullapichis, 4$5 \mathrm{~km}$ upstream from Río Pachitea, 200 m, KU 154801. Madre de Dios: Cocha Cachu, 365 m, KU 154802-03. 